\title{
ANALISIS KOMPARATIF BAURAN PROMOSI TERHADAP VOLUME PENJUALAN SEPATU SPORT ADIDAS DAN NIKE DI KABUPATEN KARAWANG
}

\author{
Reminta Lumban Batu \\ Dosen Program Studi Manajemen Fakultas Ekonomi dan Bisnis \\ Universitas Singaperbangsa Karawang \\ Email : reminta.lumban@fe.unsika.ac.id
}

\begin{abstract}
Abstrak
Penelitian ini bertujuan untuk mengetahui perbandingan bauran promosi antara sepatu sport yang ada di Karawang. Untuk Mengetahui Bagaimana gambaran Bauran PromosipadaSepatu Sport Adidas dan Nike Untuk Mengetahui Bagaimana gambaran Volume Penjualanpada Sepatu Sport Adidas dan Nike Untuk Mengetahui Seberapa besar pengaruh Bauran Promosi terhadap Volume Penjualanpada Sepatu Sport Adidas dan Nike. Sampel dalam penelitian ini sebanyak 100 responden dari masing-masing produk yang merupakan konsumen yang pernah membeli dan memakai sepatu sport Adidas dan Nike. Analisis yang digunakan adalah analisi deskriftif dan analisis verifikatif. Hasil uji beda diperoleh bahwa tidak ada perbedaan yang sigfinikan antara sepatu sport Adidas dan Nike. Dan tidak ada hubunga antara sepatu sport Adidas dan Nike.
\end{abstract}

Kata Kunci: bauran promosi, volume, penjualan

\section{Abstract}

This study aims to compare the promotional mix of sports shoes in Karawang. To find out how the description of the promotion mix on Adidas and Nike sports shoes to find out how the sales volume description on Adidas and Nike sports shoes to find out how much influence the promotional mix has on sales volume on Adidas and Nike sports shoes. The sample in this study were 100 respondents from each product who were consumers who had bought and used Adidas and Nike sports shoes. The analysis used is descriptive analysis and verification analysis. Different test results obtained that there is no significant difference between Adidas and Nike sports shoes. And there is no connection between Adidas and Nike sports shoes.

Keywords: promotion mix, volume, sales

\section{PENDAHULUAN}

Pemasaran modern pada saat ini menuntut perusahaan agar mampu untuk berkomunikasi dengan baik kepada para pelangganya,pemasok,pengecer, pihak-pihak yang memiliki kepentingan dengan perusahaan tersebut, dan juga masyarakat umum. Alat atau usaha yang dilakukan untuk mengadakan komunikasi, memberikan informasi,meyakinkan, dan memperkenalkan produk baru yang dilakukan oleh perusahaan dengan berbagai cara dikenal dengan istilah bauran promosi, yang diimplementasikan oleh setiap perusahaan dengan strateginya masing-masingdan bergantung pada kondisi perusahaan. (Didik,2013).

Pentingnya pemasaran mendorong perusahaan berusaha semaksimal mungkin untuk berhasil, yaitu dengan cara melakukan berbagai 
macam langkah-langkah strategi pemasaran yang memiliki ruang lingkup luas di bidang pemasaran diantaranya adalah strategi dalam menghadapi persaingan, strategi harga, strategi pelayanan, strategi produk, \& strategi promosi dengan tujuan untuk meningkatkan volume penjualan (Makmur, Saprijal, 2015).

Perkembangan ekonomi saat ini cenderung semakin mengarah pada persaingan ketat terutama perusahaan yang sejenis danmengakibatkan perusahaan harus mengikuti perkembangan yang ada, baik dalam bidang ekonomi, politik sosial dan budaya. Perusahaan juga harus mengikuti alur atau pola perilaku pesaing dalam menjalankan bisnisnya tersebut. Perusahaan dituntut untuk memiliki suatu inovasi yang dapat membuat konsumen tertarik dalam merebut atau mempertahankan pasar yang ada, konsumen yang kritis dalam memilih suatu produk sampai mereka memutuskan untuk membeli produk tersebut. Produk yang ditawarkan saat ini sangatlah bervariasi atau banyak macamnya dan tidak terkecuali untuk produk sepatu yang terus mengalami perkembangan yang sangat pesat. Pilihan yang bervariasi atau banyak ragamnya tersebut akan lebih memudahkan calon pembeli untuk menentukan pilihannya sesuai dengan keinginannya dan juga kemampuan ekonominya. (www.indotopinfo.com, diakses pada 21 oktober 2018, Pk. 00.03 WIB).

Perkembangan yang pesat pada industri sepatu olahraga ini di dukung oleh data yang didapat dari portal statistik yaitu Statista, Inc,tahun (2017) yang menyajikan data pendapatan penjualan sepatu dari tiga merek, yaitu Nike, Adidas, dan Puma dari Tahun 2012 sampai 2017.

TABEL 1.1

DATA PENJUALAN SEPATU OLAHRAGA DARI 3 MEREK

\begin{tabular}{|c|c|c|c|c|c|c|c|}
\hline \multirow[b]{2}{*}{ Merek } & \multicolumn{6}{|c|}{ Pendapatan per Tahun (dalam juta US \$) } & \multirow[b]{2}{*}{ Kenaikan } \\
\hline & 2012 & 2013 & 2014 & 2015 & 2016 & 2017 & \\
\hline Nike & 13.51 & 14.64 & 16.21 & 18.32 & 19.87 & 21.08 & 103.63 \\
\hline Adidas & 9.14 & 9.07 & 8.1 & 9.13 & 10.68 & 10.36 & 56.48 \\
\hline Puma & 2.11 & 1.88 & 1.56 & 1.65 & 1.71 & 2.41 & 11.32 \\
\hline Total & 24.76 & 25.59 & 25.87 & 29.1 & 32.26 & 33.85 & 171.43 \\
\hline
\end{tabular}

Sumber: (ekonomi.metrotvnews.com diakses tgl 19 oktober 2018 pkl 15.00 WIB)

Berdasarkan Tabel 1.1, diperoleh data pendapatan dari penjualan sepatu olah raga oleh 3 perusahaan. Pendapatan dari hasil penjualan sepatu olahraga oleh 3 merek tersebut mengalami kenaikan sebesar 171.43 $\%$ dari tahun 2012 sampai 2017.Perkembangan jumlah peminat sepatu olah raga meningkat dari tahun ketahun. Hasil tersebut juga dapat dilihat bahwa pendapatan Nike dan Adidas berbeda signifikan dari hasil penjualan sepatu yang paling dominan dari 3 merek yaitu mengalami kenaikan sebesar 103.63 dan 56.48 dari tahun 2012 sampai 2017. 
TABEL 1.2

TOP BRAND INDEX KATEGORI SEPATU SPORTY TAHUN 2014-2018

\begin{tabular}{|c|c|c|c|c|c|}
\hline \multirow{2}{*}{ MEREK } & \multicolumn{5}{|c|}{ TAHUN } \\
\cline { 2 - 6 } & $\mathbf{2 0 1 4}$ & $\mathbf{2 0 1 5}$ & $\mathbf{2 0 1 6}$ & $\mathbf{2 0 1 7}$ & $\mathbf{2 0 1 8}$ \\
\hline Adidas & $4,9 \%$ & $5,4 \%$ & $37,4 \%$ & $38,2 \%$ & $37,6 \%$ \\
\hline Nike & $17,9 \%$ & $18,1 \%$ & $29,6 \%$ & $32,2 \%$ & $25,6 \%$ \\
\hline Converse & $17,3 \%$ & $17 \%$ & - & $3,6 \%$ & - \\
\hline Puma & $4,2 \%$ & - & - & - & - \\
\hline Bata & $25,3 \%$ & $27,1 \%$ & $3,6 \%$ & - & - \\
\hline Dallas & - & $4,2 \%$ & - & - & - \\
\hline Reebok & - & - & $3,7 \%$ & $3,3 \%$ & $6,2 \%$ \\
\hline Eagle & - & - & $3 \%$ & $3,3 \%$ & - \\
\hline Ardiles & - & - & - & - & $5,2 \%$ \\
\hline Diadora & - & - & - & - & $4,6 \%$ \\
\hline
\end{tabular}

Sumber:www.topbrand-award.com, diakses pada tanggal 19 Oktober 2018,pukul 22.12 WIB)

Berdasarkan Tabel 1.2 menunjukkan bahwa brand Nike\&Adidas memiliki prestasi brand yang baik, dapat dilihat dari pertumbuhan Top Brand Index Nike \& Adidas yang terus meningkat dari tahun 2016 hingga 2017. Tetapi pada saat 2018 turun dan masih bisa mempertahankan peringkat di posisi pertama. Top Brand Index diukur dengan menggunakan 3 parameter, yaitu top of mind awareness atau berdasarkan merek yang pertama kali disebut oleh responden ketika kategori produknya disebutkan, last used atau berdasarkan merek yang terakhir kali digunakan atau dikonsumsi oleh responden dalam 1 re-purchase cycle, dan future intention atau berdasarkan merek yang ingin digunakan atau dikonsumsi pada masa mendatang (http://www.topbrand-award.com/, diakses pada tanggal 19 oktober 2018 pukul 23.10 WIB).

PrestasiAdidas yang baik, banyak perusahaan-perusahaan yang ingin mengambil keuntungan dengan memproduksi atau menjual sepatusepatu yang kualitasnya tidak sesuai dengan standart perusahaan atau biasa disebut dengan sepatu replika. Kegiatan memproduksi sepatu replika ini sudah lama berlangsung. Sepatu-sepatu yang banyak di produksi di China ini sengaja dibuat semirip mungkin dengan sepatu aslinya. Fenomena ini diusut karena adanya laporan yang dilakukan oleh pemegang merek Adidas di Indonesia sendiri. (http://news.liputan6.com/diakses pada 21 oktober 2018).

TABEL 1.3

PANGSA PASAR DI INDONESIA

\begin{tabular}{|l|l|}
\hline $\begin{array}{l}\text { Merek } \\
\text { Pasar }\end{array}$ & Pangsa Pasar \\
\hline Nike & $30 \%$ \\
\hline Adidas & $23 \%$ \\
\hline Reebok & $6,3 \%$ \\
\hline Bata & $4,3 \%$ \\
\hline Eagle & $3,7 \%$ \\
\hline Ardiles & $3,7 \%$ \\
\hline Others & $29 \%$ \\
\hline
\end{tabular}


Sumber: industri.bisnis.com, diakses pada tanggal 19 Oktober 2018,pukul 15.00. WIB)

Berdasarkan Table 1.3bahwa pangsa pasar di dalam negeri tahun 2017 sepatu sport Adidas masih dibawah Nike yang menjadi raja pasar di Indonesia dengan menempati posisi pertama pada tahun 2017. Sepatu Sport merek Nike merupakan saingan terberat Sepatu Sport merek Adidas.

TABEL 1.4

HASIL PENJUALAN PRODUK SEPATU DI ENAM KOTA BESAR 2017

\begin{tabular}{|l|l|l|l|l|l|l|}
\hline Merek/kota & $\begin{array}{l}\text { JAKAR } \\
\text { TA }\end{array}$ & $\begin{array}{l}\text { BAND } \\
\text { UNG }\end{array}$ & $\begin{array}{l}\text { SEMA } \\
\text { RANG }\end{array}$ & $\begin{array}{l}\text { YOGYA } \\
\text { KARTA }\end{array}$ & $\begin{array}{l}\text { SURAB } \\
\text { AYA }\end{array}$ & MEDAN \\
\hline Adidas & 23.69 & 27.72 & 23.96 & 12.77 & 12.1 & 29.15 \\
\hline Nike & 14.35 & 16.9 & 15.9 & 3.82 & 9.95 & 11.25 \\
\hline Eagle & 10.37 & 8.32 & 11.88 & 14.17 & 13.25 & 12.43 \\
\hline Bata & 6.96 & 8.58 & 1.55 & 6.78 & 9.96 & 0.72 \\
\hline Reebok & 6.89 & 7.5 & 10 & 4.32 & 4.69 & 2.09 \\
\hline Spotec & 6.31 & 3.45 & 7.67 & 4.32 & 4.84 & 31.21 \\
\hline Kasogi & 3.96 & 3.57 & 0.48 & 2.42 & 1.11 & 0.72 \\
\hline Specs & 3.56 & 3.92 & 3.5 & 1.22 & 4.25 & 1.67 \\
\hline Loggo & 2.83 & 1.93 & 1.96 & 10.43 & 4.16 & 1.2 \\
\hline Puma & 2.74 & 2.07 & 6.46 & 0.6 & 1.5 & 3.94 \\
\hline Piero & 2.21 & 1.43 & 0.95 & 7.9 & 3.53 & 2.65 \\
\hline New era & 2.03 & 1.88 & 0.39 & 6.03 & 3.38 & 0 \\
\hline Fila & 1.8 & 2.11 & 2.91 & 1.77 & 0.37 & 0 \\
\hline Convers & 1.22 & 1.27 & 2.03 & 0.59 & 0.99 & 0 \\
\hline Pro ATT & 1.09 & 1.2 & 0.76 & 2.41 & 0.97 & 0 \\
\hline Warriors & 1.03 & 1.25 & 2.11 & 0 & 0 & 0 \\
\hline
\end{tabular}

Sumber : (MARS Indonesia, diakses pada tanggal 19 oktober 2018 pukul 15.30 WIB)

Berdasarkan tabel 1.4 bahwa Adidas menempati peringkat pertama dan Nike berada di peringkat kedua di 6 kota besar Indonesia. Fenomena dari data di atas menandakan minat pembelian sepatu dengan merek Adidas masih menjadi primadona bagi konsumen dibandingkan dengan merek Nike dan sepatu sport lainnya. Penjualan Adidas global di Indonesia masih lebih baik dibanding dengan tingkat penjualan sepatu lainnya termasuk Nike.

Adidas memiliki Strategi pemasaran yang baik, dalam segala sisi Adidas berusaha mempromosikan produk mereka ke berbagai negara melalui banyak store dan beberapa media. Fenomena yang terjadi strategi pemasaran Nike lebih baik dibandingkan dengan Adidas karena Nike lebih dikenal dibandingkan dengan Adidas dan lebih menguasai pasar.

Menurut (Charles W. Lamb, Jr. Josep F Hair, Jr dan Charl McDaniel, 2001), dalam melaksanakan kegiatan promosi untuk mencapai tujuan, 
yaitu terciptanya penjualan suatu perusahaan haruslah mempunyai seperangkat alat yang memang dapat menunjang pelaksanaan program promosi yang baik. Bauran promosi adalah kombinasi dari alat promosi termasuk periklanan, hubungan masyarakat, dan promosi penjualan digunakan untuk mencapai pasar sasaran dan memenuhi tujuan organisasi secara keseluruhan. Menurut (Irmawan, 2009) Dimensi Bauran Promosi yaitu :

1. Periklanan

Periklanan adalah komunikasi non individu,dengan sejumlah biaya, melalalui berbagai media yang dilakukan oleh perusahaan,serta individu-individu.

2. Personal Selling

Personal selling adalah interaksi antar individu, saling bertemu muka, mengadakan kontak langsung, yang ditujukan untuk menciptakan, memperbaiki, menguasai, atau mempertahankan hubungan pertukaran yang saling menguntungkan dengan pihak lain.

3. Publisitas

Publisias adalah sejumlah informasi tentang seseorang,barang / organisasi yang disebarluaskan ke masyarakat melalui media tanpa dipungut biaya, atau tanpa pengawasan dari sponsor.

4. Promosi Penjualan

Kegiatan-kegiatan pemasaran selain personal selling, periklanan, dan pubisitas yang mendorong efektivitas pembelian konsumen dan pedagang dengan menggunakan alat-alat seperti peragaan, pameran, demontrasi, dan sebagainya.

5. Direct Marketing

Direct Marketing (Tiyani, 2012)adalah sistem pemasaran yang bersifat interaktif, yang memanfaatkan satu arah atau beberapa media iklan untuk menimbulkan respon yang terukur dan atau transaksi di sembarang lokasi.

Volume penjualan dikemukakan oleh Rangkuti (2009 : 207) bahwa volume penjualan adalah pencapaian yang dinyatakan secara kuantitatif dari segi fisik atau volume atau unit suatu produk. Dimensi volume penjualan yaitu :

1. Harga jual.

Faktor harga jual merupakan hal-hal yang sangat penting dan mempengaruhi penjualan atas barang atau jasa yang dihasilkan. Apakah barang atau jasa yang ditawarkan oleh perusahaan dapat dijangkau oleh konsumen sasaran.

2. Produk.

Produk salah satu faktor yang mempengaruhi tingkat volume penjualan sebagai barang atau jasa yang ditawarkan oleh perusahaan apakah sesuai dengan tingkat kebutuhan para konsumen.

3. Mutu 
Mutu dan kualitas barnag merupakan salah satu faktor yang mempengaruhi volume penjualan. Dengan mutu yang baik maka konsumen akan tetap loyal terhadap produk dari perusahaan tesebut, begitu pula sebaliknya apabila mutu produk yang ditawarkan tidak bagus maka konsumen akan berpaling kepada produk lain.

\section{Kerangka Pemikiran}

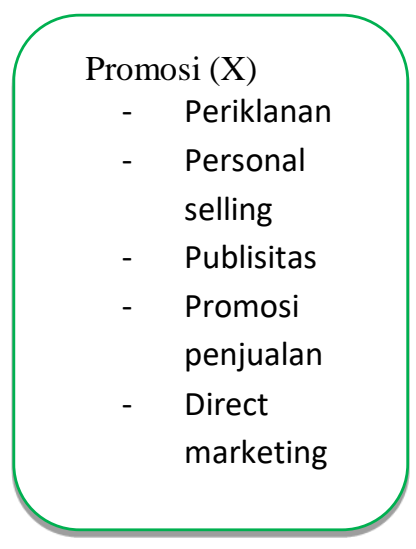

\section{Gambar 2.1 \\ Kerangka pemikiran}

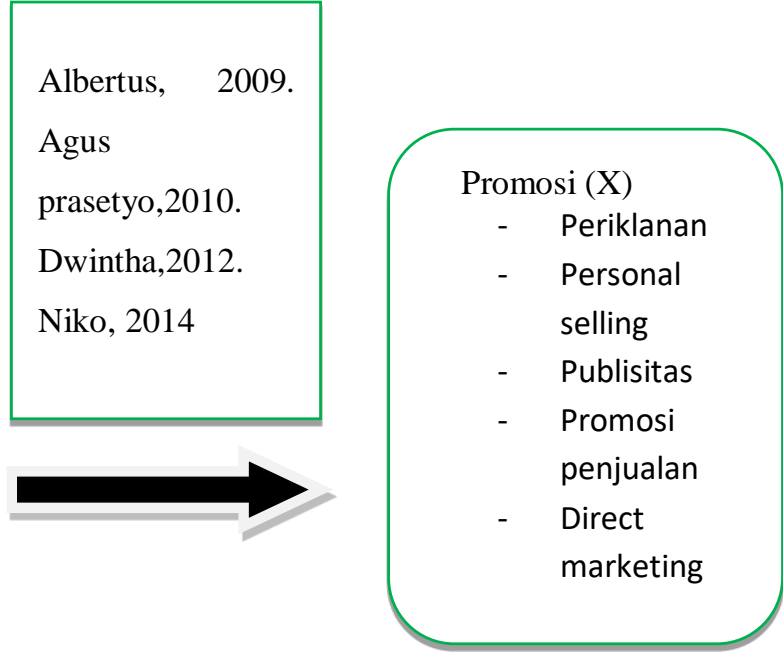

Dari hasil kerangka pemikiran di atas dapat disimpulkan hipotesis dari penelitian ini, yaitu "Bauran Promosi berpengaruh terhadap Volume Penjualan pada sepatu sport Adidas dan Nike.

\section{METODE PENELITIAN}

Jenis Penelitian ini adalah Kuantitatif. Menurut Martono (2010:19) menyatakan penelitian kuantitatif adalah penelitian dengan mengumpulkan data yang berupa angka. Data yang data yang berupa angka tersebut kemudian diolah dan di analisis untuk mendapatkan suatu informasi ilmiah dibalik angka-angka tersebut.

\section{Waktu dan Tempat Penelitian}

Penelitian ini dilakukan di Karawang, Jawa Barat. Waktu pelaksanaan penelitian dilaksanakan pada bulan Oktober 2018 sampai dengan bulan Desember 2018

\section{Populasi dan Sampel}

Menurut Sugiyono (2012:80), populasi adalah wilayah generalisasi yang terdiri atas obyek atau subyek yang mempunyai kualitas dan karakteristik tertentu yang ditetapkan oleh peneliti untuk dipelajari dan kemudian ditarik kesimpulannya (Sugianto, 2017). Populasi dalam penelitian ini adalah seluruh konsumen atau masayarakat di Karawang di atas 15 Tahun yaitu sebanyak 1.673 .184 orang. Rumus yang digunakan dalam pengambilan sampel ini adalah berdasarkan rumus Slovin dan menghasilkan sampel sebanyak 100 orang. 


\section{Uji Validitas}

Validitas menurut Sugiyono (2016:177) menunjukan derajat ketepatan antara data yang sesungguhnya terjadi pada objek dengan data yang dikumpulkan oleh peneliti untuk mencari validitas sebuah item dengan mengkorelasikan skor item dengan total item-item tersebut. Jika koefisien antara item dengan total item sama atau diatas 0,3 maka item tersebut dinyatakan valid, tetapi jika nilai korelasinya dibawah 0,3 maka item tersebut dinyatakan tidak valid.

\section{Uji Reliabilitas}

Hasil penelitian yang reliabel, bila terdapat kesamaan data dalam waktu yang berbeda (Sugiyono 2011:121) Uji reliabilitas dilakukan untuk mengetahui apakah alat ukur yang dirancang dalam bentuk kuesioner dapat diandalkan, suatu alat ukur dapat diandalkan jika alat ukur tersebut digunakan berulangkali akan memberikan hasil yang relatif sama (tidak berbeda jauh).

\section{Teknik Analisis Data}

Analisis deskriptif digunakan untuk melihat faktor penyebab dengan mencari kuatnya hubungan antara variable tanpa perlu diuji signifikasinya, penelitian ini menggunakan analisis deskriptif dengan menggunakan kuisioner yang disebarkan kepada responden agar diperoleh deskripsi tentang variable-variabel penelitian

Teknik data verifikatif yang digunakan ialah dengan persamaan regresi. Penelitian ini menggunakan bantuan program software SPSS for Windows (Statistic Product and Services Solution) versi 24 untuk menunjukkan hubungan antara variabel terikat $(Y)$ dengan variable bebas (X) melalui analisis regresi sederhana.

\section{HASIL ANALSIS DATA}

TABEL 1

PROFIL BERDASARKAN JENIS KELAMIN

Adidas

\begin{tabular}{|c|c|c|c|c|c|}
\hline & & Frequency & Percent & Valid Percent & $\begin{array}{l}\text { Cumulative } \\
\text { Percent }\end{array}$ \\
\hline \multirow[t]{3}{*}{ Valid } & Laki - Laki & 31 & 31,0 & 31,0 & 31,0 \\
\hline & Perempuan & 69 & 69,0 & 69,0 & 100,0 \\
\hline & Total & 100 & 100,0 & 100,0 & \\
\hline \multicolumn{6}{|c|}{ Nike } \\
\hline & & Frequency & Percent & Valid Percent & $\begin{array}{l}\text { Cumulative } \\
\text { Percent }\end{array}$ \\
\hline \multirow[t]{3}{*}{ Valid } & Laki - Laki & 28 & 28,0 & 28,0 & 28,0 \\
\hline & Perempuan & 72 & 72,0 & 72,0 & 100,0 \\
\hline & Total & 100 & 100,0 & 100,0 & \\
\hline
\end{tabular}

Sumber : Hasil Pengolahan Data, 2018 
Tabel 1 menunjukkan bahwa sebagian besar responden sepatu adalah perempuan yaitu sebesar $72 \%$ untuk nike dan $69 \%$ untuk adidas

\section{Profil PT. Sepatu Sport Adidas dan Nike Cabang Karawang} Berdasarkan Profesi

Pengumpulan data melalui kuesioner mengenai karakteristik responden berdasarkan profesi disajikan pada Tabel 4.2 berikut ini.

TABEL 2

PROFIL BERDASARKAN PROFESI

Adidas

\begin{tabular}{|c|c|c|c|c|c|}
\hline \\
\hline & & Frequency & Percent & Valid Percent & $\begin{array}{l}\text { Cumulative } \\
\text { Percent }\end{array}$ \\
\hline \multirow[t]{4}{*}{ Valid } & Karyawan & 30 & 30,0 & 30,0 & 30,0 \\
\hline & Mahasiswa/Pelajar & 55 & 55,0 & 55,0 & 85,0 \\
\hline & Others & 15 & 15,0 & 15,0 & 100,0 \\
\hline & Total & 100 & 100,0 & 100,0 & \\
\hline \multicolumn{6}{|c|}{ Nike } \\
\hline & & Frequency & Percent & Valid Percent & $\begin{array}{l}\text { Cumulative } \\
\text { Percent }\end{array}$ \\
\hline \multirow[t]{4}{*}{ Valid } & Karyawan & 22 & 22,0 & 22,0 & 22,0 \\
\hline & Mahasiswa/Pelajar & 66 & 66,0 & 66,0 & 88,0 \\
\hline & Others & 12 & 12,0 & 12,0 & 100,0 \\
\hline & Total & 100 & 100,0 & 100,0 & \\
\hline
\end{tabular}

Sumber : Hasil Pengolahan Data, 2018

Tabel 2 menunjukkan bahwa sebagian besar responden berprofesi sebagai mahasiswa/pelajar dengan $66 \%$ untuk nike dan $55 \%$ untuk adidas, diikuti oleh profesi karyawan yaitu $22 \%$ untuk nike dan $30 \%$ untuk adidas.

Profil PT. Sepatu Sport Adidas dan Nike Cabang Karawang Berdasarkan Umur 15 ke atas Penduduk Karawang

Pengumpulan data melalui kuesioner mengenai karakteristik responden berdasarkan jenis kelamin disajikan pada Tabel 4.3 berikut ini.

\section{TABEL 3}

PROFIL BERDASARKAN UMUR 15 TAHUN KE ATAS

Adidas

\begin{tabular}{|c|c|c|c|c|c|}
\hline & & Frequency & Percent & Valid Percent & $\begin{array}{l}\text { Cumulative } \\
\text { Percent }\end{array}$ \\
\hline \multirow[t]{5}{*}{ Valid } & > 30 Tahun & 9 & 9,0 & 9,0 & 9,0 \\
\hline & 15 - 18 Tahun & 18 & 18,0 & 18,0 & 27,0 \\
\hline & 19 - 23 Tahun & 50 & 50,0 & 50,0 & 77,0 \\
\hline & 24 - 30 Tahun & 23 & 23,0 & 23,0 & 100,0 \\
\hline & Total & 100 & 100,0 & 100,0 & \\
\hline \multicolumn{6}{|c|}{ Nike } \\
\hline & & Frequency & Percent & Valid Percent & $\begin{array}{l}\text { Cumulative } \\
\text { Percent }\end{array}$ \\
\hline \multirow[t]{5}{*}{ Valid } & $>30$ Tahun & 5 & 5,0 & 5,0 & 5,0 \\
\hline & 15 - 18 Tahun & 24 & 24,0 & 24,0 & 29,0 \\
\hline & 19 - 23 Tahun & 56 & 56,0 & 56,0 & 85,0 \\
\hline & 24 - 30 Tahun & 15 & 15,0 & 15,0 & 100,0 \\
\hline & Total & 100 & 100,0 & 100,0 & \\
\hline
\end{tabular}

Sumber : Hasil Pengolahan Data, 2018 
Tabel 3 menunjukkan bahwa sebagian besar responden nike adalah usia anatara 19 - 23 tahun dengan 56\% dilanjutkan dengan usia antara 1518 tahun dengan 24\%, sedangkan untuk adidas yaitu sebgaian besar usia antara 19-23 tahun dilanjutkan dengan usia antara 24-30 tahun.

\section{Profil PT. Sepatu Sport Adidas dan Nike Cabang Karawang} Berdasarkan Gaji Perbulan

Pengumpulan data melalui kuesioner mengenai karakteristik responden berdasarkan jenis kelamin disajikan pada Tabel 4berikut ini.

TABEL 4

BERDASARKAN GAJI PERBULAN

Adidas

\begin{tabular}{|c|c|c|c|c|c|c|}
\hline & & & Frequency & Percent & $\begin{array}{l}\text { Valid } \\
\text { Percent }\end{array}$ & $\begin{array}{l}\text { Cumulative } \\
\text { Percent }\end{array}$ \\
\hline \multirow[t]{5}{*}{ Valid } & $<$ Rp 3.000.000 & & 56 & 56,0 & 56,0 & 56,0 \\
\hline & $>$ Rp 10.000.000 & & 10 & 10,0 & 10,0 & 66,0 \\
\hline & $\begin{array}{l}\text { Rp } \quad 3.000 .000 \\
5.000 .000\end{array}$ & Rp & 20 & 20,0 & 20,0 & 86,0 \\
\hline & $\begin{array}{l}\text { Rp } \quad 5.000 .000 \\
10.000 .000\end{array}$ & - $R p$ & 14 & 14,0 & 14,0 & 100,0 \\
\hline & Total & & 100 & 100,0 & 100,0 & \\
\hline
\end{tabular}

\begin{tabular}{|c|c|c|c|c|c|c|}
\hline \multicolumn{7}{|c|}{ Nike } \\
\hline & & & Frequency & Percent & $\begin{array}{l}\text { Valid } \\
\text { Percent }\end{array}$ & $\begin{array}{l}\text { Cumulative } \\
\text { Percent }\end{array}$ \\
\hline \multirow[t]{5}{*}{ Valid } & $<\operatorname{Rp} 3.000 .000$ & & 67 & 67,0 & 67,0 & 67,0 \\
\hline & $>\operatorname{Rp} 10.000 .000$ & & 7 & 7,0 & 7,0 & 74,0 \\
\hline & $\begin{array}{l}\text { Rp } 3.000 .000 \\
5.000 .000\end{array}$ & $\mathrm{Rp}$ & 14 & 14,0 & 14,0 & 88,0 \\
\hline & $\begin{array}{l}\mathrm{Rp} \quad 5.000 .000 \\
10.000 .000\end{array}$ & $\mathrm{Rp}$ & 12 & 12,0 & 12,0 & 100,0 \\
\hline & Total & & 100 & 100,0 & 100,0 & \\
\hline
\end{tabular}

Sumber : Hasil Pengolahan Data, 2018

Tabel 4 menunjukkan bahwa sebagian besar responden yaitu bergaji kurang dari 3.000.000 rupiah, dilanjutkan dengan yang bergaji antara 3.000.000 - 5.000.000 dan responden yang paling sedikit yaitu yang bergaji lebih dari 10.000 .000 rupiah.

\section{Analisis Deskriptif}

\section{Gambaran Variabel Promosi (X)}

Gambaran yang merupakan hasil dari penyebaran kuesioner kepada responden dalam variabel promosi ini bertujuan untuk memperoleh jawaban mengenai sejauh mana promosiyang diterapkan oleh responden dalam hal ini adalah Sepatu Sport Adidas dan Nike. Gambaran responden terhadap promosi berdasarkan pada hasil pengolahan data yang telah 
dilakukan sehingga dapat diketahui melalui pengukuran persentase jawaban responden pada setiap pernyataan.

\section{Gambaran Dimensi X1 (Direct Marketing)}

Gambaran dimensi direct marketing bertujuan untuk memperoleh jawaban mengenai sejauh mana direct marketing dipertimbangkan oleh responden dan mampu mempengaruhi kemampuan perusahaan untuk meningkatkan volume penjualan.

TABEL 5

GAMBARAN DIMENSI DIRECT MARKETING

\begin{tabular}{|c|c|c|c|c|c|c|c|c|c|c|c|c|c|c|}
\hline \multirow{2}{*}{$\begin{array}{c}\text { Variab } \\
\text { el } \\
\text { Penelit } \\
\text { ian }\end{array}$} & \multirow[b]{2}{*}{$\begin{array}{c}\text { Perusah } \\
\text { aan }\end{array}$} & \multirow[b]{2}{*}{$\begin{array}{l}\text { Ite } \\
\text { m }\end{array}$} & \multicolumn{2}{|c|}{1} & \multicolumn{2}{|c|}{2} & \multicolumn{2}{|c|}{3} & \multicolumn{2}{|c|}{4} & \multicolumn{2}{|c|}{5} & \multirow{2}{*}{$\begin{array}{c}\text { Ra } \\
\text { ta - } \\
\text { Ra } \\
\text { ta }\end{array}$} & \multirow[b]{2}{*}{$\begin{array}{c}\text { Kateg } \\
\text { ori }\end{array}$} \\
\hline & & & $\mathbf{F}$ & $\%$ & $\mathrm{~F}$ & $\%$ & $f$ & $\%$ & $f$ & $\%$ & $f$ & $\%$ & & \\
\hline \multirow{11}{*}{$\begin{array}{c}\text { Direct } \\
\text { Marketi } \\
\text { ng (X1) }\end{array}$} & \multirow{4}{*}{ Adidas } & $\begin{array}{l}X 1 \\
.1\end{array}$ & $\begin{array}{l}3 \\
4 \\
\end{array}$ & $\begin{array}{l}34 \\
\%\end{array}$ & $\begin{array}{l}4 \\
2 \\
\end{array}$ & $\begin{array}{l}42 \\
\%\end{array}$ & $\begin{array}{l}1 \\
7\end{array}$ & $\begin{array}{l}17 \\
\%\end{array}$ & 5 & $\begin{array}{l}5 \\
\%\end{array}$ & 2 & $\begin{array}{l}2 \\
\%\end{array}$ & $\begin{array}{c}1,9 \\
9\end{array}$ & $\begin{array}{c}\text { Jaran } \\
\text { g }\end{array}$ \\
\hline & & $\begin{array}{l}\mathrm{X} 1 \\
.2 \\
\end{array}$ & 3 & $\begin{array}{l}3 \\
\% \\
\end{array}$ & $\begin{array}{l}1 \\
0 \\
\end{array}$ & $\begin{array}{l}10 \\
\% \\
\end{array}$ & $\begin{array}{l}4 \\
0 \\
\end{array}$ & $\begin{array}{l}40 \\
\% \\
\end{array}$ & $\begin{array}{l}4 \\
2 \\
\end{array}$ & $\begin{array}{l}42 \\
\% \\
\end{array}$ & 5 & $\begin{array}{l}5 \\
\% \\
\end{array}$ & $\begin{array}{c}3,3 \\
6\end{array}$ & $\begin{array}{c}\text { Tertar } \\
\text { ik }\end{array}$ \\
\hline & & $\begin{array}{l}\mathrm{X} 1 \\
.3\end{array}$ & 6 & $\begin{array}{l}6 \\
\%\end{array}$ & $\begin{array}{l}3 \\
0\end{array}$ & $\begin{array}{l}30 \\
\%\end{array}$ & $\begin{array}{l}2 \\
8\end{array}$ & $\begin{array}{l}28 \\
\%\end{array}$ & $\begin{array}{l}3 \\
2\end{array}$ & $\begin{array}{l}32 \\
\%\end{array}$ & 4 & $\begin{array}{l}4 \\
\%\end{array}$ & $\begin{array}{c}2,9 \\
8\end{array}$ & $\begin{array}{c}\text { Cuku } \\
p \\
\text { Tahu }\end{array}$ \\
\hline & & $\begin{array}{r}\mathrm{X} 1 \\
.4\end{array}$ & $\begin{array}{l}1 \\
2\end{array}$ & $\begin{array}{l}12 \\
\%\end{array}$ & $\begin{array}{l}4 \\
3\end{array}$ & $\begin{array}{l}43 \\
\%\end{array}$ & $\begin{array}{l}2 \\
4\end{array}$ & $\begin{array}{l}24 \\
\%\end{array}$ & $\begin{array}{l}1 \\
9\end{array}$ & $\begin{array}{l}19 \\
\%\end{array}$ & 2 & $\begin{array}{l}2 \\
\%\end{array}$ & $\begin{array}{c}2,5 \\
6\end{array}$ & Jauh \\
\hline & \multicolumn{12}{|c|}{ Rata - Rata Skor Variabel Direct Marketing Adidas } & $\begin{array}{c}2,7 \\
2\end{array}$ & $\begin{array}{l}\text { Cuku } \\
\text { p Baik }\end{array}$ \\
\hline & \multirow{4}{*}{ Nike } & $\begin{array}{l}\mathrm{X} 1 \\
.1\end{array}$ & $\begin{array}{l}2 \\
5\end{array}$ & $\begin{array}{l}25 \\
\%\end{array}$ & $\begin{array}{l}4 \\
4\end{array}$ & $\begin{array}{l}44 \\
\%\end{array}$ & $\begin{array}{l}2 \\
1\end{array}$ & $\begin{array}{l}21 \\
\%\end{array}$ & 9 & $\begin{array}{l}9 \\
\%\end{array}$ & 1 & $\begin{array}{l}1 \\
\%\end{array}$ & $\begin{array}{c}2,1 \\
7\end{array}$ & $\begin{array}{c}\text { Jaran } \\
\mathrm{g}\end{array}$ \\
\hline & & $\begin{array}{l}X 1 \\
.2\end{array}$ & 3 & $\begin{array}{l}3 \\
\%\end{array}$ & $\begin{array}{l}1 \\
5\end{array}$ & $\begin{array}{l}15 \\
\%\end{array}$ & $\begin{array}{l}4 \\
5\end{array}$ & $\begin{array}{l}45 \\
\%\end{array}$ & $\begin{array}{l}3 \\
0\end{array}$ & $\begin{array}{l}30 \\
\%\end{array}$ & 7 & $\begin{array}{l}7 \\
\%\end{array}$ & $\begin{array}{c}3,2 \\
3\end{array}$ & $\begin{array}{c}\text { Cuku } \\
\mathrm{p} \\
\text { Tertar } \\
\text { ik }\end{array}$ \\
\hline & & $\begin{array}{l}\mathrm{X} 1 \\
.3\end{array}$ & 7 & $\begin{array}{l}7 \\
\%\end{array}$ & $\begin{array}{l}2 \\
8\end{array}$ & $\begin{array}{l}28 \\
\%\end{array}$ & $\begin{array}{l}4 \\
2\end{array}$ & $\begin{array}{l}42 \\
\%\end{array}$ & $\begin{array}{l}1 \\
8\end{array}$ & $\begin{array}{l}18 \\
\%\end{array}$ & 5 & $\begin{array}{l}5 \\
\%\end{array}$ & $\begin{array}{c}2,8 \\
6\end{array}$ & $\begin{array}{c}\text { Cuku } \\
p \\
\text { Tahu }\end{array}$ \\
\hline & & $\begin{array}{l}\mathrm{X} 1 \\
.4 \\
\end{array}$ & $\begin{array}{l}1 \\
4 \\
\end{array}$ & $\begin{array}{l}14 \\
\%\end{array}$ & $\begin{array}{l}3 \\
9\end{array}$ & $\begin{array}{l}39 \\
\%\end{array}$ & $\begin{array}{l}3 \\
4 \\
\end{array}$ & $\begin{array}{l}34 \\
\%\end{array}$ & $\begin{array}{l}1 \\
2 \\
\end{array}$ & $\begin{array}{l}12 \\
\%\end{array}$ & 1 & $\begin{array}{l}1 \\
\%\end{array}$ & $\begin{array}{c}2,4 \\
7\end{array}$ & Jauh \\
\hline & \multicolumn{12}{|c|}{ Rata - Rata Skor Variabel Direct Marketing Nike } & $\begin{array}{c}2,6 \\
8\end{array}$ & $\begin{array}{l}\text { Cuku } \\
\text { p Baik }\end{array}$ \\
\hline & \multicolumn{12}{|c|}{ Mean } & $\begin{array}{c}2,7 \\
0\end{array}$ & $\begin{array}{l}\text { Cuku } \\
\text { p Baik }\end{array}$ \\
\hline
\end{tabular}

Sumber : Hasil Pengolahan Data, 2018

Berdasarkan Tabel 5 untuk variable direct marketing didapatkan rata-rata sepatu sport Adidas dengan kategori yang cukup baik dengan nilai rata-rata 2,7 sedangkan untuk rata-rata sepatu sport nike mendapatkan kategori cukup baik dengan nilai rata-rata 2,68. Dari hasil keduanya maka mendapatkan mean dengan nilai 2,70 yang kategorinya cukup baik.

\section{Gambaran Dimensi X2 (Publisitas)}

Gambaran dimensi publisitas bertujuan untuk memperoleh jawaban mengenai sejauh mana publisitas dipertimbangkan oleh responden dan mampu mempengaruhi kemampuan perusahaan untuk meningkatkan volume penjualan. 
TABEL 6

GAMBARAN DIMENSI PUBLISITAS

\begin{tabular}{|c|c|c|c|c|c|c|c|c|c|c|c|c|c|c|}
\hline \multirow{2}{*}{$\begin{array}{l}\text { Variabel } \\
\text { Penelitian }\end{array}$} & \multirow[b]{2}{*}{ Perusahaan } & \multirow[b]{2}{*}{ Item } & \multicolumn{2}{|c|}{1} & \multicolumn{2}{|c|}{2} & \multicolumn{2}{|c|}{3} & \multicolumn{2}{|c|}{4} & \multicolumn{2}{|c|}{5} & \multirow{2}{*}{$\begin{array}{c}\text { Rata } \\
- \\
\text { Rata }\end{array}$} & \multirow[b]{2}{*}{ Kategori } \\
\hline & & & $\mathbf{F}$ & $\%$ & $F$ & $\%$ & $F$ & $\%$ & $F$ & $\%$ & $f$ & $\%$ & & \\
\hline \multirow{9}{*}{$\begin{array}{l}\text { PUBLISITAS } \\
(\mathrm{X} 2)\end{array}$} & \multirow{3}{*}{ Adidas } & $\mathrm{X} 2.1$ & 1 & $1 \%$ & 8 & $8 \%$ & 35 & $35 \%$ & 46 & $46 \%$ & 10 & $10 \%$ & 3,56 & Tertarik \\
\hline & & $X 2.2$ & 1 & $1 \%$ & 9 & $9 \%$ & 47 & $47 \%$ & 41 & $41 \%$ & 2 & $2 \%$ & 3,34 & $\begin{array}{l}\text { cukup } \\
\text { Tertarik }\end{array}$ \\
\hline & & $\mathrm{X} 2.3$ & 2 & $2 \%$ & 16 & $16 \%$ & 30 & $30 \%$ & 37 & $37 \%$ & 15 & $15 \%$ & 3,47 & Sering \\
\hline & \multicolumn{12}{|c|}{ Rata - Rata Skor Variabel Publisitas Adidas } & 3,46 & Baik \\
\hline & \multirow{3}{*}{ Nike } & $\mathrm{X} 2.1$ & 1 & $1 \%$ & 11 & $11 \%$ & 37 & $37 \%$ & 40 & $40 \%$ & 11 & $11 \%$ & 3,49 & Tertarik \\
\hline & & X2.2 & 3 & $3 \%$ & 11 & $11 \%$ & 40 & $40 \%$ & 36 & $36 \%$ & 10 & $10 \%$ & 3,39 & $\begin{array}{l}\text { cukup } \\
\text { Tertarik }\end{array}$ \\
\hline & & $X 2.3$ & 7 & $7 \%$ & 16 & $16 \%$ & 34 & $34 \%$ & 35 & $35 \%$ & 8 & $8 \%$ & 3,21 & $\begin{array}{l}\text { Cukup } \\
\text { Sering }\end{array}$ \\
\hline & \multicolumn{12}{|c|}{ Rata - Rata Skor Variabel Publisitas Nike } & 3,36 & $\begin{array}{l}\text { Cukup } \\
\text { Baik }\end{array}$ \\
\hline & & & & & & Mean & & & & & & & 3,41 & Baik \\
\hline
\end{tabular}

Sumber : Hasil Pengolahan Data, 2018

Berdasarkan Tabel 6 untuk variable publisitas didapatkan rata-rata sepatu sport Adidas dengan kategori yang baik dengan nilai rata-rata 3,46 sedangkan untuk rata-rata sepatu sport nike mendapatkan kategori cukup baik dengan nilai rata-rata 3,36 Dari hasil keduanya maka mendapatkan mean dengan nilai 3,41 yang kategorinya baik

Gambaran Dimensi X3 (Personal Selling)

Gambaran dimensi personal selling bertujuan untuk memperoleh jawaban mengenai sejauh mana personal sellingdipertimbangkan oleh responden dan mampu mempengaruhi kemampuan perusahaan untuk meningkatkan volume penjualan.

TABEL 7

GAMBARAN DIMENSI PERSONAL SELLING

\begin{tabular}{|c|c|c|c|c|c|c|c|c|c|c|c|c|c|c|}
\hline \multirow{2}{*}{$\begin{array}{l}\text { Variabel } \\
\text { Penelitian }\end{array}$} & \multirow[b]{2}{*}{ Perusahaan } & \multirow[b]{2}{*}{ Item } & \multicolumn{2}{|c|}{1} & \multicolumn{2}{|c|}{2} & \multicolumn{2}{|c|}{3} & \multicolumn{2}{|c|}{4} & \multicolumn{2}{|c|}{5} & \multirow{2}{*}{$\begin{array}{c}\text { Rata } \\
- \\
\text { Rata }\end{array}$} & \multirow[b]{2}{*}{ Kategori } \\
\hline & & & $\mathbf{F}$ & $\%$ & $f$ & $\%$ & $F$ & $\%$ & $\mathrm{~F}$ & $\%$ & $f$ & $\%$ & & \\
\hline \multirow{8}{*}{$\begin{array}{c}\text { PERSONAL } \\
\text { SELLING } \\
\text { (X3) }\end{array}$} & \multirow{3}{*}{ Adidas } & X3.1 & 1 & $1 \%$ & 14 & $14 \%$ & 51 & $51 \%$ & 28 & $28 \%$ & 6 & $6 \%$ & 3,24 & $\begin{array}{l}\text { Cukup } \\
\text { Tertarik }\end{array}$ \\
\hline & & X3.2 & 2 & $2 \%$ & 7 & $7 \%$ & 51 & $51 \%$ & 31 & $31 \%$ & 9 & $9 \%$ & 3,38 & $\begin{array}{l}\text { Cukup } \\
\text { Tertarik }\end{array}$ \\
\hline & & X3.3 & 1 & $1 \%$ & 6 & $6 \%$ & 41 & $41 \%$ & 45 & $45 \%$ & 7 & $7 \%$ & 3,51 & Paham \\
\hline & \multicolumn{12}{|c|}{ Rata - Rata Skor Variabel Personal Selling Adidas } & 3,38 & $\begin{array}{l}\text { Cukup } \\
\text { Baik }\end{array}$ \\
\hline & \multirow{3}{*}{ Nike } & X3.1 & 0 & $0 \%$ & 14 & $14 \%$ & 49 & $49 \%$ & 31 & $31 \%$ & 6 & $6 \%$ & 3,29 & $\begin{array}{l}\text { Cukup } \\
\text { Tertarik }\end{array}$ \\
\hline & & X3.2 & 2 & $2 \%$ & 10 & $10 \%$ & 55 & $55 \%$ & 26 & $26 \%$ & 7 & $7 \%$ & 3,26 & $\begin{array}{l}\text { Cukup } \\
\text { Tertarik }\end{array}$ \\
\hline & & X3.3 & 3 & $3 \%$ & 8 & $8 \%$ & 40 & $40 \%$ & 43 & $43 \%$ & 6 & $6 \%$ & 3,41 & Paham \\
\hline & \multicolumn{12}{|c|}{ Rata - Rata Skor Variabel Personal Selling Nike } & 3,32 & $\begin{array}{l}\text { Cukup } \\
\text { Baik }\end{array}$ \\
\hline
\end{tabular}




\begin{tabular}{|c|c|c|}
\cline { 2 - 3 } & Mean & Cukup \\
Baik
\end{tabular}

Sumber : Hasil Pengolahan Data, 2018

Berdasarkan Tabel 7 untuk variable Personal Selling didapatkan rata-rata sepatu sport Adidas dengan kategori yang baik dengan nilai ratarata 3,38 sedangkan untuk rata-rata sepatu sport nike mendapatkan kategori cukup baik dengan nilai rata-rata 3,36 Dari hasil keduanya maka mendapatkan mean dengan nilai 3,32 yang kategorinya cukup baik.

\section{Gambaran Dimensi X4 (Advertising)}

Gambaran dimensi Advertising bertujuan untuk memperoleh jawaban mengenai sejauh mana Advertising dipertimbangkan oleh responden dan mampu mempengaruhi kemampuan perusahaan untuk meningkatkan volume penjualan.

TABEL 8

GAMBARAN DIMENSI ADVERTISING

\begin{tabular}{|c|c|c|c|c|c|c|c|c|c|c|c|c|c|c|}
\hline \multirow{2}{*}{$\begin{array}{l}\text { Variabel } \\
\text { Penelitian }\end{array}$} & \multirow[b]{2}{*}{ Perusahaan } & \multirow[b]{2}{*}{ Item } & \multicolumn{2}{|c|}{1} & \multicolumn{2}{|c|}{2} & \multicolumn{2}{|c|}{3} & \multicolumn{2}{|c|}{4} & \multicolumn{2}{|c|}{5} & \multirow{2}{*}{$\begin{array}{c}\text { Rata } \\
\text { - } \\
\text { Rata }\end{array}$} & \multirow[b]{2}{*}{ Kategor } \\
\hline & & & f & $\%$ & $\mathrm{~F}$ & $\%$ & $\mathrm{~F}$ & $\%$ & $f$ & $\%$ & $f$ & $\%$ & & \\
\hline \multirow{9}{*}{$\begin{array}{l}\text { ADVERTISING } \\
(\mathrm{X} 4)\end{array}$} & \multirow{3}{*}{ Adidas } & $X 4.1$ & 3 & $3 \%$ & 35 & $35 \%$ & 24 & $24 \%$ & 28 & $28 \%$ & 10 & $10 \%$ & 3,07 & $\begin{array}{l}\text { Cukup } \\
\text { Sering }\end{array}$ \\
\hline & & $\mathrm{X} 4.2$ & 0 & $0 \%$ & 6 & $6 \%$ & 40 & $40 \%$ & 46 & $46 \%$ & 8 & $8 \%$ & 3,56 & Tertarik \\
\hline & & $X 4.3$ & 5 & $5 \%$ & 15 & $15 \%$ & 29 & $29 \%$ & 39 & $39 \%$ & 12 & $12 \%$ & 3,38 & $\begin{array}{l}\text { Cukup } \\
\text { Tertarik }\end{array}$ \\
\hline & \multicolumn{12}{|c|}{ Rata - Rata Skor Variabel Advertising Adidas } & 3,34 & $\begin{array}{c}\text { Cukup } \\
\text { Baik }\end{array}$ \\
\hline & \multirow{3}{*}{ Nike } & $X 4.1$ & 7 & $7 \%$ & 33 & $33 \%$ & 22 & $22 \%$ & 32 & $32 \%$ & 6 & $6 \%$ & 2,97 & $\begin{array}{l}\text { Cukup } \\
\text { Sering }\end{array}$ \\
\hline & & $\mathrm{X} 4.2$ & 1 & $1 \%$ & 7 & $7 \%$ & 40 & $40 \%$ & 44 & $44 \%$ & 8 & $8 \%$ & 3,51 & Tertarik \\
\hline & & $\mathrm{X} 4.3$ & 2 & $2 \%$ & 14 & $14 \%$ & 35 & $35 \%$ & 32 & $32 \%$ & 17 & $17 \%$ & 3,48 & Tertarik \\
\hline & \multicolumn{12}{|c|}{ Rata - Rata Skor Variabel Advertising Nike } & 3,32 & $\begin{array}{l}\text { Cukup } \\
\text { Baik }\end{array}$ \\
\hline & \multicolumn{12}{|c|}{ Mean } & 3,33 & $\begin{array}{l}\text { Cukup } \\
\text { Baik }\end{array}$ \\
\hline
\end{tabular}

Sumber : Hasil Pengolahan Data, 2018

Berdasarkan Tabel 8 untuk variable advertising didapatkan rata-rata sepatu sport Adidas dengan kategori yang cukup baik dengan nilai rata-rata 3,34 sedangkan untuk rata-rata sepatu sport nike mendapatkan kategori cukup baik dengan nilai rata-rata 3,32. Dari hasil keduanya maka mendapatkan mean dengan nilai 3,33 yang kategorinya cukup.

\section{Gambaran Variabel Volume Penjualan (Y)}

Gambaran yang merupakan hasil dari penyebaran kuesioner kepada responden dalam variabel volume penjualan ini bertujuan untuk memperoleh jawaban mengenai sejauh mana volume penjualan yang diterapkan oleh responden dalam hal ini adalah Sepatu Sport Adidas dan Nike. Gambaran responden terhadap peningkatan volume penjualan berdasarkan pada hasil pengolahan data yang telah dilakukan sehingga dapat diketahui melalui pengukuran persentase jawaban responden pada setiap pernyataan. 


\section{Gambaran Dimensi Y1 (Harga)}

Gambaran dimensi harga bertujuan untuk memperoleh jawaban mengenai sejauh mana hargadipertimbangkan oleh responden dan mampu mempengaruhi kemampuan perusahaan untuk meningkatkan volume penjualan.

TABEL 9

GAMBAR DIMENSI HARGA

\begin{tabular}{|c|c|c|c|c|c|c|c|c|c|c|c|c|c|c|}
\hline \multirow{2}{*}{$\begin{array}{l}\text { Variabel } \\
\text { Penelitian }\end{array}$} & \multirow[b]{2}{*}{ Perusahaan } & \multirow[b]{2}{*}{ Item } & \multicolumn{2}{|c|}{1} & \multicolumn{2}{|c|}{2} & \multicolumn{2}{|c|}{3} & \multicolumn{2}{|c|}{4} & \multicolumn{2}{|c|}{5} & \multirow{2}{*}{$\begin{array}{c}\text { Rata } \\
- \\
\text { Rata }\end{array}$} & \multirow[b]{2}{*}{ Kategori } \\
\hline & & & f & $\%$ & $\mathrm{~F}$ & $\%$ & $\mathrm{~F}$ & $\%$ & $\mathrm{~F}$ & $\%$ & $f$ & $\%$ & & \\
\hline \multirow{9}{*}{$\begin{array}{c}\text { HARGA } \\
(Y 1)\end{array}$} & \multirow{3}{*}{ Adidas } & Y1.1 & 3 & $3 \%$ & 18 & $18 \%$ & 56 & $56 \%$ & 21 & $21 \%$ & 2 & $2 \%$ & 3,01 & $\begin{array}{c}\text { Cukup } \\
\text { Terjangkau }\end{array}$ \\
\hline & & Y1.2 & 1 & $1 \%$ & 2 & $2 \%$ & 30 & $30 \%$ & 53 & $53 \%$ & 14 & $14 \%$ & 3,77 & Sesuai \\
\hline & & Y1.3 & 0 & $0 \%$ & 2 & $2 \%$ & 27 & $27 \%$ & 57 & $57 \%$ & 14 & $14 \%$ & 3,83 & Sesuai \\
\hline & \multicolumn{12}{|c|}{ Rata - Rata Skor Variabel Harga Adidas } & 3,54 & Baik \\
\hline & \multirow{3}{*}{ Nike } & Y1.1 & 3 & $3 \%$ & 21 & $21 \%$ & 56 & $56 \%$ & 18 & $18 \%$ & 2 & $2 \%$ & 2,95 & $\begin{array}{l}\text { Cukup } \\
\text { Terjangkau }\end{array}$ \\
\hline & & Y1.2 & 0 & $0 \%$ & 5 & $5 \%$ & 26 & $26 \%$ & 55 & $55 \%$ & 14 & $14 \%$ & 3,78 & Sesuai \\
\hline & & Y1.3 & 0 & $0 \%$ & 2 & $2 \%$ & 30 & $30 \%$ & 57 & $57 \%$ & 11 & $11 \%$ & 3,77 & Sesuai \\
\hline & \multirow{2}{*}{\multicolumn{12}{|c|}{ Rata - Rata Skor Variabel Harga Nike }} & 3,50 & Baik \\
\hline & & & & & & Mean & & & & & & & 3,52 & Baik \\
\hline
\end{tabular}

Sumber : Pengolahan Data, 2018

Berdasarkan Tabel 9 untuk variable harga didapatkan rata-rata sepatu sport Adidas dengan kategori yang baik dengan nilai rata-rata 3,54 sedangkan untuk rata-rata sepatu sport nike mendapatkan kategori baik dengan nilai rata-rata 3,50. Dari hasil keduanya maka mendapatkan mean dengan nilai 3,52 yang kategorinya baik.

\section{Gambaran Dimensi Y2 (Mutu)}

Gambaran dimensi mutu bertujuan untuk memperoleh jawaban mengenai sejauh mana mutudipertimbangkan oleh responden dan mampu mempengaruhi kemampuan perusahaan untuk meningkatkan volume penjualan.

TABEL 10

GAMBAR DIMENSI MUTU

\begin{tabular}{|c|c|c|c|c|c|c|c|c|c|c|c|c|c|c|}
\hline \multirow[b]{2}{*}{$\begin{array}{l}\text { Variabel } \\
\text { Penelitian }\end{array}$} & \multirow[b]{2}{*}{ Perusahaan } & \multirow[b]{2}{*}{ Item } & \multicolumn{2}{|c|}{1} & \multicolumn{2}{|c|}{2} & \multicolumn{2}{|c|}{3} & \multicolumn{2}{|c|}{4} & \multicolumn{2}{|c|}{5} & \multirow{2}{*}{$\begin{array}{c}\text { Rata } \\
\text { - } \\
\text { Rata }\end{array}$} & \multirow[b]{2}{*}{ Kategori } \\
\hline & & & $f$ & $\%$ & $F$ & $\%$ & $f$ & $\%$ & $f$ & $\%$ & $\mathrm{~F}$ & $\%$ & & \\
\hline \multirow{9}{*}{$\begin{array}{c}\text { MUTU } \\
\text { (Y2) }\end{array}$} & \multirow{3}{*}{ Adidas } & Y2.1 & 0 & $0 \%$ & 5 & $5 \%$ & 39 & $39 \%$ & 45 & $45 \%$ & 11 & $11 \%$ & 3,62 & Unik \\
\hline & & Y2.2 & 0 & $0 \%$ & 3 & $3 \%$ & 20 & $20 \%$ & 58 & $58 \%$ & 19 & $19 \%$ & 3,93 & Awet \\
\hline & & Y2.3 & 0 & $0 \%$ & 1 & $1 \%$ & 24 & $24 \%$ & 60 & $60 \%$ & 15 & $15 \%$ & 3,89 & $\begin{array}{c}\text { Percaya } \\
\text { Diri }\end{array}$ \\
\hline & \multicolumn{12}{|c|}{ Rata - Rata Skor Variabel Mutu Adidas } & 3,81 & Baik \\
\hline & \multirow{3}{*}{ Nike } & Y2.1 & 0 & $0 \%$ & 3 & $3 \%$ & 36 & $36 \%$ & 49 & $49 \%$ & 12 & $12 \%$ & 3,7 & Unik \\
\hline & & Y2.2 & 0 & $0 \%$ & 4 & $4 \%$ & 22 & $22 \%$ & 54 & $54 \%$ & 20 & $20 \%$ & 3,9 & Awet \\
\hline & & Y2.3 & 0 & $0 \%$ & 2 & $2 \%$ & 28 & $28 \%$ & 51 & $51 \%$ & 19 & $19 \%$ & 3,87 & $\begin{array}{c}\text { Percaya } \\
\text { Diri }\end{array}$ \\
\hline & \multicolumn{12}{|c|}{ Rata - Rata Skor Variabel Mutu Nike } & 3,82 & Baik \\
\hline & \multicolumn{12}{|c|}{ Mean } & 3,82 & Baik \\
\hline
\end{tabular}

Sumber : Pengolahan Data, 2018 
Berdasarkan Tabel 10 Ountuk variable mutu didapatkan rata-rata sepatu sport Adidas dengan kategori yang baik dengan nilai rata-rata 3,81 sedangkan untuk rata-rata sepatu sport nike mendapatkan kategori baik dengan nilai rata-rata 3,82. Dari hasil keduanya maka mendapatkan mean dengan nilai 3,82 yang kategorinya baik.

\section{Gambaran Dimensi Y1 (Produk)}

Gambaran dimensi produk bertujuan untuk memperoleh jawaban mengenai sejauh mana produkdipertimbangkan oleh responden dan mampu mempengaruhi kemampuan perusahaan untuk meningkatkan volume penjualan.

TABEL 11

GAMBAR DIMENSI PRODUK

\begin{tabular}{|c|c|c|c|c|c|c|c|c|c|c|c|c|c|c|}
\hline \multirow{2}{*}{$\begin{array}{l}\text { Variabel } \\
\text { Penelitian }\end{array}$} & \multirow[b]{2}{*}{ Perusahaan } & \multirow[b]{2}{*}{ Item } & \multicolumn{2}{|c|}{1} & \multicolumn{2}{|c|}{2} & \multicolumn{2}{|c|}{3} & \multicolumn{2}{|c|}{4} & \multicolumn{2}{|c|}{5} & \multirow{2}{*}{$\begin{array}{c}\text { Rata } \\
- \\
\text { Rata }\end{array}$} & \multirow[b]{2}{*}{ Kategori } \\
\hline & & & f & $\%$ & $F$ & $\%$ & $F$ & $\%$ & $f$ & $\%$ & $f$ & $\%$ & & \\
\hline \multirow{9}{*}{$\begin{array}{c}\text { PRODUK } \\
\text { (Y3) }\end{array}$} & \multirow{3}{*}{ Adidas } & Y3.1 & 0 & $0 \%$ & 2 & $2 \%$ & 27 & $27 \%$ & 55 & $55 \%$ & 16 & $16 \%$ & 3,85 & Menarik \\
\hline & & Y3.2 & 0 & $0 \%$ & 0 & $0 \%$ & 19 & $19 \%$ & 66 & $66 \%$ & 15 & $15 \%$ & 3,96 & Sesuai \\
\hline & & Y3.3 & 0 & $0 \%$ & 0 & $0 \%$ & 44 & $44 \%$ & 40 & $40 \%$ & 16 & $16 \%$ & 3,72 & Tinggi \\
\hline & \multicolumn{12}{|c|}{ Rata - Rata Skor Variabel Produk Adidas } & 3,84 & Baik \\
\hline & \multirow{3}{*}{ Nike } & Y3.1 & 0 & $0 \%$ & 2 & $2 \%$ & 31 & $31 \%$ & 52 & $52 \%$ & 15 & $15 \%$ & 3,8 & Menarik \\
\hline & & Y3.2 & 0 & $0 \%$ & 3 & $3 \%$ & 24 & $24 \%$ & 55 & $55 \%$ & 18 & $18 \%$ & 3,88 & Sesuai \\
\hline & & Y3.3 & 0 & $0 \%$ & 1 & $1 \%$ & 43 & $43 \%$ & 39 & $39 \%$ & 17 & $17 \%$ & 3,72 & Tinggi \\
\hline & \multicolumn{12}{|c|}{ Rata - Rata Skor Variabel Produk Nike } & 3,80 & Baik \\
\hline & \multicolumn{12}{|c|}{ Mean } & 3,82 & Baik \\
\hline
\end{tabular}

Sumber : Pengolahan Data, 2018

Berdasarkan Tabel 11 untuk variable produk didapatkan rata-rata sepatu sport Adidas dengan kategori yang baik dengan nilai rata-rata 3,84 sedangkan untuk rata-rata sepatu sport nike mendapatkan kategori baik dengan nilai rata-rata 3,80. Dari hasil keduanya maka mendapatkan mean dengan nilai 3,82 yang kategorinya baik.

\section{Analisis Verifikatif \\ Analisi Korelasi}

1. Adidas

\begin{tabular}{|l|l|l|l|}
\hline \multicolumn{4}{|c|}{ Correlations } \\
\hline \multicolumn{2}{|c|}{} & Y & X \\
\hline Pearson Correlation & Y & 1,000 &, 696 \\
\cline { 2 - 4 } & X &, 696 & 1,000 \\
\hline \multirow{2}{*}{ Sig. (1-tailed) } & Y &. &, 000 \\
\cline { 2 - 4 } & X &, 000 &. \\
\hline N & Y & 100 & 100 \\
\cline { 2 - 4 } & X & 100 & 100 \\
\hline
\end{tabular}


2. Nike

\begin{tabular}{|c|c|c|c|}
\hline \multicolumn{4}{|c|}{ Correlations } \\
\hline & & $\mathrm{Y}$ & $\mathrm{X}$ \\
\hline \multirow{2}{*}{ Pearson Correlation } & Y & 1,000 & ,669 \\
\hline & $\mathrm{X}$ & ,669 & 1,000 \\
\hline \multirow[t]{2}{*}{ Sig. (1-tailed) } & $\mathrm{Y}$ & &, 000 \\
\hline & $\mathrm{X}$ &, 000 & \\
\hline \multirow[t]{2}{*}{$\mathrm{N}$} & Y & 100 & 100 \\
\hline & X & 100 & 100 \\
\hline
\end{tabular}

Hipotesis:

$\mathrm{HO}: \rho=0$ (tidak ada hubungan linier antara $\mathrm{x}$ dan $\mathrm{y}$ )

$\mathrm{H} 1: \rho \neq 0$ (ada hubungan linier antara $x$ dan $y$ )

Berdasarkan output SPSS, korelasi antara variabel penjelas dan variabel respon, masing-masing memiliki $P$-value $<0.1$. sehingga keputusan tolak $\mathrm{H}_{0}$, artinya dengan kepercayaan $90 \%$ setiap variabel penjelas memiliki hubungan linier (korelasi) yang nyata terhadap variabel respon. Diikuti dengan nilai korelasi yang cukup tinggi.

\section{Uji Normalitas}

1. Adidas

One-Sample Kolmogorov-Smirnov Test

\begin{tabular}{|l|l|l|}
\hline \multicolumn{2}{|l|}{ One-Sample Kolmogorov-Smirnov Test } \\
\hline \multirow{2}{|l|}{ N } & $\begin{array}{l}\text { Unstandardized } \\
\text { Residual }\end{array}$ \\
\hline \multirow{2}{*}{ Normal Parameters } & \\
& Mean & 100 \\
\cline { 2 - 3 } & Std. Deviation &, 0000000 \\
\hline \multirow{2}{*}{ Most Extreme Differences } & Absolute &, 076 \\
\cline { 2 - 3 } & Positive &, 061 \\
\cline { 2 - 3 } & Negative &,- 076 \\
\hline Test Statistic &, 076 \\
\hline Asymp. Sig. (2-tailed) &, $159^{c}$ \\
\hline
\end{tabular}

Dengan menggunakan uji kenormalan Kolmogorov-Smirnov P-value pada uji kenormalan KS sebesar $0.159>0,05$. dapat diketahui bahwa residual menyebar normal pada Adidas.

2. Nike

One-Sample Kolmogorov-Smirnov Test

\begin{tabular}{|l|l|l|}
\hline \multicolumn{2}{|l|}{ One-Sample Kolmogorov-Smirnov Test } \\
\hline \multicolumn{2}{|l|}{} \\
\hline \multirow{2}{*}{ N } & $\begin{array}{l}\text { Unstandardized } \\
\text { Residual }\end{array}$ \\
\hline Normal Parameters & Mean & 100 \\
\cline { 2 - 3 } & Std. Deviation &, 0000000 \\
\hline \multirow{2}{*}{ Most Extreme Differences } & Absolute &, 064 \\
\cline { 2 - 3 } & Positive &, 064 \\
\cline { 2 - 3 } & Negative &,- 059 \\
\hline Test Statistic &, 064 \\
\hline Asymp. Sig. (2-tailed) & &, $200^{\mathrm{c}, \mathrm{d}}$ \\
\hline
\end{tabular}

Dengan menggunakan uji kenormalan Kolmogorov-Smirnov P-value pada uji kenormalan KS sebesar $0.200>0,05$. dapat diketahui bahwa residual menyebar normal pada Nike. 
Berdasarkan Perbandingan diatas diketahui bahwa residual lebih menyebar normal pada Nike.

Homosketdastisitas

1. Adidas

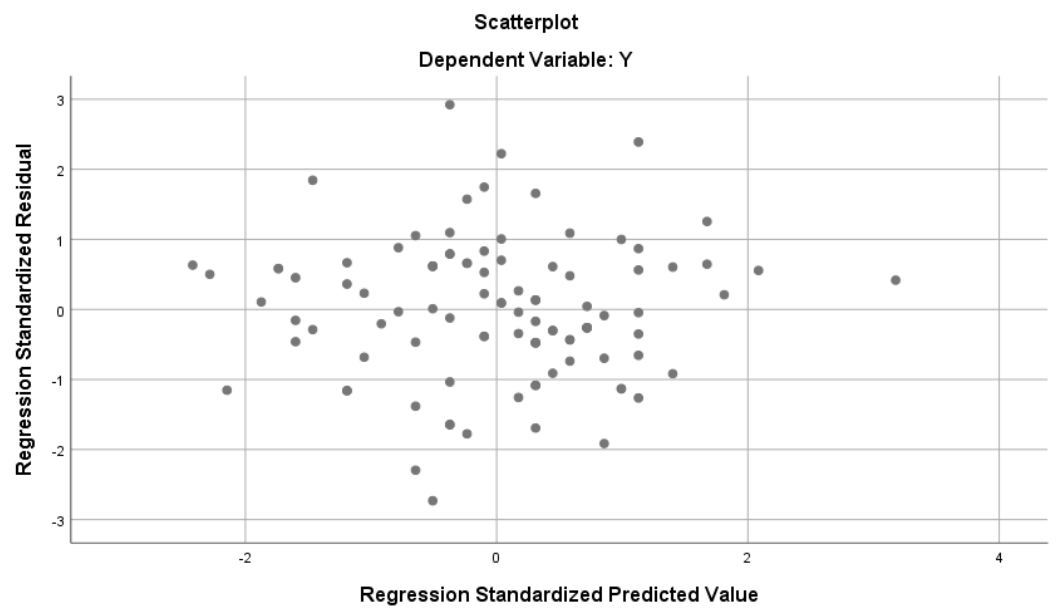

2. Nike

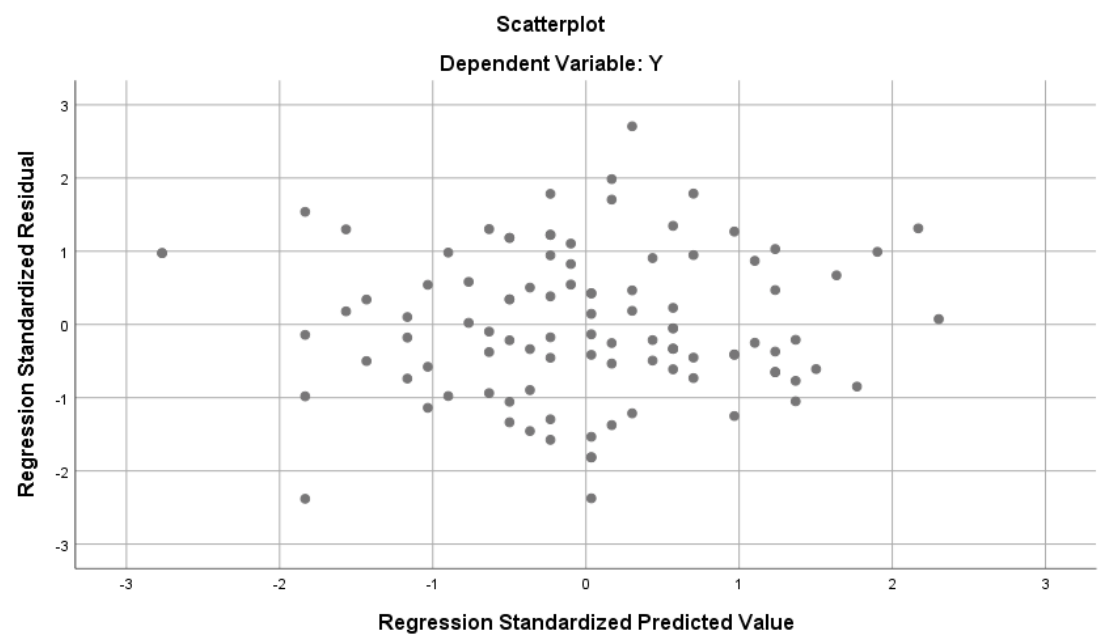

Berdasarkan grafik di residual menyebar secara acak, tidak mengikuti pola tertentu, sehingga dapat disimpulkan bahwa galat mempunyai ragam yang sama. Dengan demikian, asumsi Homoskedastisitas terpenuhi 


\section{Non Auto Korelasi}

$\mathrm{H}_{0}: \rho=0$ (tidak terdapat autokorelasi)

$\mathrm{H}_{1}: \rho \neq 0$ (terdapat autokorelasi

\section{Adidas}

\section{Model Summary}

\begin{tabular}{|c|c|c|c|c|c|c|c|c|c|c|}
\hline $\begin{array}{l}\text { Mod } \\
\text { el }\end{array}$ & $\mathrm{R}$ & $\begin{array}{l}\mathrm{R} \\
\text { Squar } \\
\mathrm{e}\end{array}$ & $\begin{array}{l}\text { Adjusted } \\
\text { R Square }\end{array}$ & $\begin{array}{l}\text { Std. } \\
\text { Error of } \\
\text { the } \\
\text { Estimate }\end{array}$ & $\begin{array}{l}\text { Change S } \\
\text { R Square } \\
\text { Change }\end{array}$ & $\begin{array}{l}\text { tatistics } \\
\text { F } \\
\text { Chang } \\
\text { e }\end{array}$ & df1 & df2 & $\begin{array}{l}\text { Sig. } F \\
\text { Change }\end{array}$ & $\begin{array}{l}\text { Durbin- } \\
\text { Watson }\end{array}$ \\
\hline 1 &, $696^{a}$ & ,484 & ,479 & 3,284 & ,484 & $\begin{array}{l}91,92 \\
3\end{array}$ & 1 & 98 &, 000 & 1,813 \\
\hline
\end{tabular}

Tabel Durbin Watson $\mathrm{k}=2, \mathrm{n}=100$, alfa $=0,05: \mathrm{dL}=1.6337 \quad \mathrm{du}=1.7152$ Jika $\mathrm{d}>\mathrm{du}$ maka tidak tolak $\mathrm{H}_{0}$. Jadi, dari uji Durbin Watson dapat disimpulkan bahwa tidak terjadi autokorelasi, asumsi non autokorelasi terpenuhi.

2. Nike

\begin{tabular}{|c|c|c|c|c|c|c|c|c|c|c|}
\hline \multicolumn{11}{|c|}{ Model Summaryb } \\
\hline \multirow[b]{2}{*}{$\begin{array}{l}\text { Mo } \\
\text { del }\end{array}$} & \multirow[b]{2}{*}{$\mathrm{R}$} & \multirow[b]{2}{*}{$\begin{array}{l}\text { R } \\
\text { Squar } \\
\text { e }\end{array}$} & \multirow[b]{2}{*}{$\begin{array}{l}\text { Adjusted } \\
\mathrm{R} \\
\text { Square }\end{array}$} & \multirow{2}{*}{$\begin{array}{l}\text { Std. } \\
\text { Error of } \\
\text { the } \\
\text { Estimate }\end{array}$} & \multicolumn{5}{|c|}{ Change Statistics } & \multirow[b]{2}{*}{$\begin{array}{l}\text { Durbin- } \\
\text { Watson }\end{array}$} \\
\hline & & & & & $\begin{array}{l}\mathrm{R} \\
\text { Square } \\
\text { Change }\end{array}$ & $\begin{array}{l}\text { F } \\
\text { Chan } \\
\text { ge }\end{array}$ & df1 & df2 & $\begin{array}{l}\text { Sig. } F \\
\text { Change }\end{array}$ & \\
\hline 1 & $669^{a}$ & ,448 & ,442 & 3,572 & ,448 & $\begin{array}{l}79,41 \\
3\end{array}$ & 1 & 98 & ,000 & 2,127 \\
\hline
\end{tabular}

Tabel Durbin Watson $\mathrm{k}=2, \mathrm{n}=100$, alfa $=0,05: \mathrm{dL}=1.6337 \quad \mathrm{du}=1.7152$ Jika $d>d u$ maka tidak tolak $H_{0}$. Jadi, dari uji Durbin Watson dapat disimpulkan bahwa tidak terjadi autokorelasi, asumsi non autokorelasi terpenuhi.

\section{Non Multikolinieritas}

\section{Adidas}

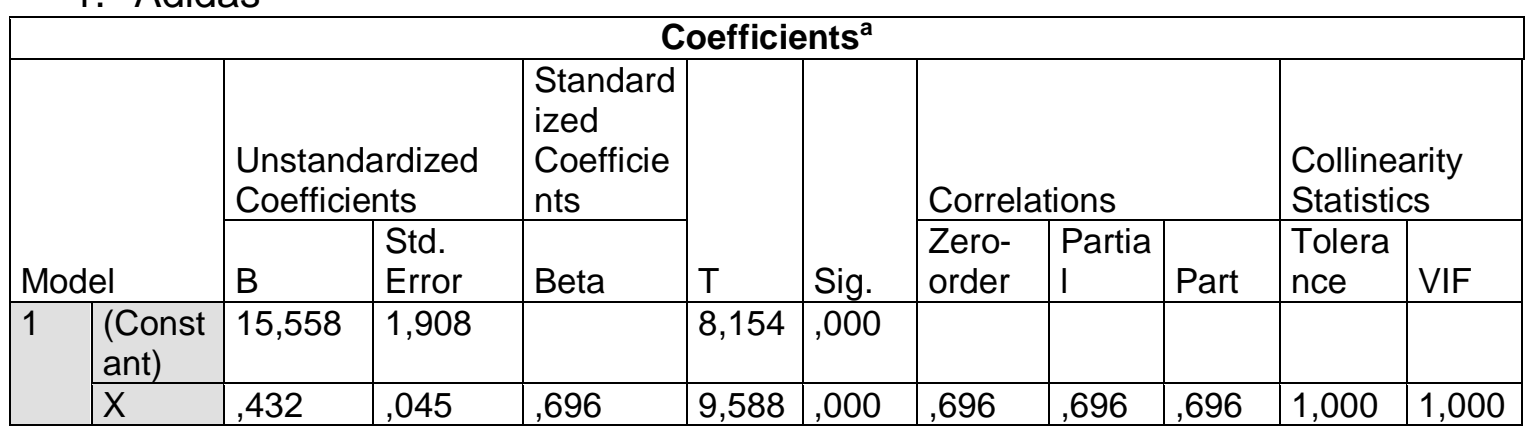

2. Nike

\begin{tabular}{|c|c|c|c|c|c|c|c|c|c|c|}
\hline A & & & & & & & & & & \\
\hline \multirow[b]{2}{*}{ Model } & \multicolumn{2}{|c|}{$\begin{array}{l}\text { Unstandardized } \\
\text { Coefficients }\end{array}$} & \multirow{2}{*}{$\begin{array}{l}\text { Standar } \\
\text { dized } \\
\text { Coefficie } \\
\text { nts } \\
\text { Beta }\end{array}$} & \multirow[b]{2}{*}{$t$} & \multirow[b]{2}{*}{ Sig. } & \multicolumn{3}{|c|}{ Correlations } & \multicolumn{2}{|c|}{$\begin{array}{l}\text { Collinearity } \\
\text { Statistics }\end{array}$} \\
\hline & B & $\begin{array}{l}\text { Std. } \\
\text { Error }\end{array}$ & & & & $\begin{array}{l}\text { Zero- } \\
\text { order }\end{array}$ & $\begin{array}{l}\text { Parti } \\
\text { al }\end{array}$ & Part & $\begin{array}{l}\text { Tolera } \\
\text { nce }\end{array}$ & VIF \\
\hline
\end{tabular}




\begin{tabular}{|l|l|l|l|l|l|l|l|l|l|l|l|}
\hline 1 & $\begin{array}{l}\text { (Const } \\
\text { ant) }\end{array}$ & 15,982 & 1,984 & & 8,057 &, 000 & & & & & \\
\hline & $\mathrm{X}$ &, 427 &, 048 &, 669 & 8,911 &, 000 &, 669 &, 669 &, 669 & 1,000 & 1,000 \\
\hline
\end{tabular}

\section{Uji simultan}

Hipotesis:

$\mathrm{H}_{0}$ : peubah $\mathrm{X}$ tidak mempengaruhi $\mathrm{Y}$ secara bersama-sama

$\mathrm{H}_{1}$ : minimal ada satu peubah $X$ yang mempengaruhi $Y$

\section{Adidas}

\begin{tabular}{|c|c|c|c|c|c|c|}
\hline \multicolumn{7}{|c|}{ ANOVA $^{a}$} \\
\hline \multicolumn{2}{|c|}{ Model } & Sum of Squares & $d f$ & Mean Square & $\mathrm{F}$ & Sig. \\
\hline \multirow[t]{3}{*}{1} & Regression & 991,411 & 1 & 991,411 & 91,923 &, $000^{b}$ \\
\hline & Residual & 1056,949 & 98 & 10,785 & & \\
\hline & Total & 2048,360 & 99 & & & \\
\hline
\end{tabular}

2. Nike

\begin{tabular}{|c|c|c|c|c|c|c|}
\hline \multicolumn{7}{|c|}{ ANOVA $^{a}$} \\
\hline \multicolumn{2}{|c|}{ Model } & Sum of Squares & df & Mean Square & $\mathrm{F}$ & Sig. \\
\hline \multirow[t]{3}{*}{1} & Regression & 1013,096 & 1 & 1013,096 & 79,413 &, $000^{\mathrm{b}}$ \\
\hline & Residual & 1250,214 & 98 & 12,757 & & \\
\hline & Total & 2263,310 & 99 & & & \\
\hline
\end{tabular}

Pengujian secara simultan dilakukkan dengan uji statistik $F$, berdasarkan output SPSS didapatkan P-value $0.000<0.05$, sehingga keputusan tolak $H_{0}$. Artinya, minimal ada satu peubah penjelas $x$ mempengaruhi peubah respon $\mathrm{Y}$.

\section{Uji Parsial}

1. Adidas

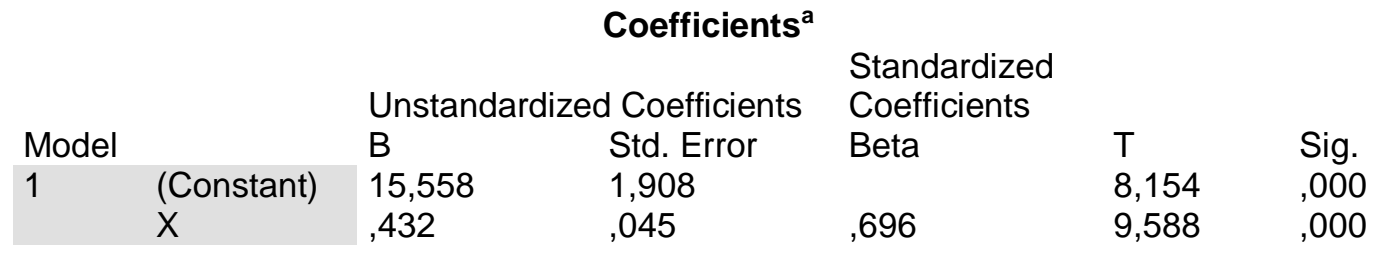

2. Nike

\section{Coefficients $^{\mathrm{a}}$}

\begin{tabular}{|c|c|c|c|c|c|}
\hline \multirow{2}{*}{\multicolumn{2}{|c|}{ Model }} & \multicolumn{2}{|c|}{ Unstandardized Coefficients } & \multicolumn{2}{|c|}{ Coefficients } \\
\hline & & & Std. Error & Beta & $\mathrm{t}$ \\
\hline 1 & $\begin{array}{l}\text { (Constant) } \\
X\end{array}$ & $\begin{array}{l}15,982 \\
, 427\end{array}$ & $\begin{array}{l}1,984 \\
, 048\end{array}$ & & $\begin{array}{l}8,057 \\
8,911\end{array}$ \\
\hline
\end{tabular}

\section{Determinasi}

\section{Adidas}

\section{Model Summary ${ }^{\mathrm{b}}$}

$\mathrm{R}$ 


\begin{tabular}{|l|l|l|l|l|l|l|l|l|l|l|}
\hline $\begin{array}{l}\text { Mod } \\
\text { el }\end{array}$ & & $\begin{array}{l}\text { R } \\
\text { Squar } \\
\text { e }\end{array}$ & $\begin{array}{l}\text { Adjusted } \\
\text { R Square }\end{array}$ & $\begin{array}{l}\text { Std. Error } \\
\text { of the } \\
\text { Estimate }\end{array}$ & $\begin{array}{l}\text { R Square } \\
\text { Change }\end{array}$ & $\begin{array}{l}\text { F } \\
\text { Chang } \\
\text { e }\end{array}$ & df1 & df2 & $\begin{array}{l}\text { Sig. F } \\
\text { Change }\end{array}$ & $\begin{array}{l}\text { Durbin- } \\
\text { Watson }\end{array}$ \\
\hline 1 &, $696^{\mathrm{a}}$ &, 484 &, 479 & 3,284 &, 484 & 91,92 & 1 & 98 &, 000 & 1,813 \\
\hline
\end{tabular}

Berdasarkan output SPSS, nilai $\mathrm{R}^{2}$ sebesar 0.484 artinya $48.4 \%$ keragaman jumlah volume penjualan (Y) Adidas dapat dijelaskan oleh faktor-faktor dalam model $(\mathrm{X})$. Sisanya dijelakan faktor lain yang tidak masuk dalam model.

2. Nike

\begin{tabular}{|l|l|l|l|l|l|l|l|l|l|l|}
\hline \multicolumn{2}{|l|}{ Model Summary } \\
\hline
\end{tabular}

Berdasarkan output SPSS, nilai $R^{2}$ sebesar 0.448 artinya $44.8 \%$ keragaman jumlah volume penjualan (Y) Nike dapat dijelaskan oleh faktorfaktor dalam model $(X)$. Sisanya dijelakan faktor lain yang tidak masuk dalam model. Berdasarkan perbandingan diatas maka diketahui bahwa variabel bauran promosi lebih berpengaruh terhadap volume penjualan di Adidas yaitu dengan selisih 3,6\% dari Nike.

\section{PEMBAHASAN}

\section{Pengaruh Bauran Promosi terhadap Volume Penjualan}

Berdasarkan hasil analisis verifikatif bauran promosi meliputi Advertising, Personal Seling, Publisitas, dan Direct Marketing mempunyai rata-rata skor responden 3,19 atau berada pada kategori cukup. Hal ini menunjukan bahwa bauran promosi pada sepatu Adidas dan Nike dinilai berdasarkan persepsi responden telah dapat memberikan pengaruh pada volume penjualan terhadap sepatu Adidas dan Nike di Karawang.Berdasarkan hasil uji beda bauran promosi pada Sepatu Sport Adidas dan Nike di Karawang diketahui bahwa tidak ada perbedaan bauran promosi antara Sepatu Sport Adidas dan Nike di Karawang.

Berdasarkan uraian diatas maka dapat dijelaskan, jika pihak Adidas dan Nike ingin meningkatkan jumlah pelanggannya, maka pihak Adidas dan Nike harus menerapakan bauran pemasaran yang lebih baik lagi, diantaranya harga yang disesuaikan dengan kualitas. Selanjutnya promosi, harus gencar dengan lebih banyak melakukan discount yang lebih besar lagi. Hal ini jika dapat diterapkan, maka akan dapat menentukan jumlah pelanggan yang dating untuk membeli produk sepatu Adidas dan Nike.

\section{SIMPULAN DAN SARAN}

Berdasarkan hasil penelitian yang telah dilakukan menggunakan analisis deskriptif dan verifikatif maka berdasarkan penelitian tersebut dapat diambil kesimpulan sebagai berikut: 
a) Gambaran variabel promosi nilai diukur melalui dimensi direct marketing, publisitas, personal selling dan advertising. Rata-rata skor tertinggi terdapat pada dimensi publisitas.

b) Gambaran variabelvolume penjualan melalui dimensi harga, mutu dan produk. Rata-rata skor tertinggi terdapat pada dimensi mutu dan produk.

c) Terdapat pengaruh positif bauran promosi terhadap volume penjualan sepatu sport Adidas dan Nike Karawang

Penelitian yang lebih lanjut dan lebih baik, bisa mengambil dan menggunakan merek sepatu olahraga yang lainnya yang bertujuan untuk mengeneralisasi kesimpulan dari penelitian ini. Penelitian yang lebih lanjut juga dianjurkan untuk membandingkan merek yang terkenal dan kurang terkenal untuk melihat perbandingan perbedaan dalam manfaat terkait produk dan manfaat terkait nama merek, dan bisa juga mengambil obyek penelitian tentang produk selain sepatu olah raga dengan jumlah yang lebih banyak. Bila didapatkan variabel-variabel tambahan yang kiranya bisa digunakan sebagai pembanding, dapat juga ditambahkan dalam penelitian yang lebih lanjut guna memperkaya dan lebih melengkapi referensi bagi pihak yang berkompetenterkait penelitian ini.

\section{DAFTAR PUSTAKA}

Didik, D. (2013). ( Studi Kasus PT . Astra Internasional Tbk-TSO Cabang Soetoyo Malang ). Pengaruh Promosi Penjualan Terhadap Penjualan, 2(1), 1-8.

Makmur \& Saprijal. (2

015). STRATEGI PEMASARAN DALAM MENINGKATKAN VOLUME PENJUALAN (Studi Pada S-Mart Swalayan Pasir Pengaraian). Jurnal Ilmiah Cano Ekonomos, 3(1), 41-56. https://doi.org/10.30606/CE.V3I1.1260

Irmawan, A. O. (2009). Pengaruh biaya promosi terhadap volume penjualan.

Pradana, N. A. (2014). Pengaruh Promosi Terhadap Volume Penjualan Program Studi Manajemen.

Rachmawati, R. (Universitas N. S. (2011). Peranan bauran pemasaran (marketing mix) terhadap peningkatan penjualan (sebuah kajian terhadap bisnis restoran). Jurnal Kompetensi Teknik, 2(2), 143-150. https://doi.org/1869

Sola Asisi, R. (2007). ANALISIS PERBANDINGAN BRAND EQUITY INDOMIE DENGAN MIE SEDAAP (studi kasus pada mahasiswa Universitas Negeri Semarang).

Sugianto, H. (2017). STUDI PERBANDINGAN BAURAN PEMASARAN ANTARA IMPERIAL HOTEL DENGAN HORISON HOTEL DI KOTA KENDARI. Marketing Mix, 91, 399-404.

Sulaiman. (2012). Skripsi Pengaruh Bauran Promosi ( Promotional Mix ) Terhadap Peningkatan Penjualan Pada Universitas Islam Negeri, (Promotional Mix). 
Tiyani, D. R. (2012). Analisis Bauran Promosi Dalam Meningkatkan Volume Penjualan Mobil Daihatsu Pada PT. Jujur Jaya Sakti Makassar. 